\title{
ANALYSIS OF CONCEPTUAL SCIENTIFIC AND PRACTICAL APPROACHES TO THE MANAGEMENT OF THE HIGHER EDUCATION SYSTEM
}

\section{Klymeniuk M. M.}

\section{INTRODUCTION}

Education is one of the most complex institutions of socialization. Society ensures its development through education. There are several approaches to the analysis of educational development.

The first approach was based on the goal of education, which was formulated as the regulatory ideal of an educated person in society. This industry penetrates into all spheres of life, but is always integrated into the corresponding historical era. Karl Mannheim said that the purpose of education is reflected not only by the era, but also by the country. So, the stages of development of education should be considered in accordance with regulatory ideals. For example, in Sparta, the warrior is the central interest, in Athens - the speaker, and in a socialist society, the ideal, according to Shulmann, was a morally consistent, gradual builder of communism.

The second approach assumes that the basis of the development of education is a type of culture. Followers of this approach are Mead, Simon, Coombs, Ilyin. They argue that the development of civilization is marked by a change in the dominant types, in accordance with them, education is changing as a translator of culture. Education becomes mass and divorced from the source of knowledge.

The third, institutional approach is based on the stages of institutionalization of the education system. As a dominant, the normative, state-determined nature of education is highlighted (Durkheim, Mannheim). Education is considered as a system of targeted impact on the younger generation with the aim of adapting it to the needs of society. The domestic system of education fixated on this approach.

Given the features of the approaches described, their use depending on the socio-economic development of society, it is advisable to determine the 
basis of the concept of building management of the higher education system of Ukraine at this stage, including:

- the orientation of the higher education system to meet the needs of the state in qualified specialists, which is a prerequisite for the intensive development of the country;

- increasing the level of providing each member of the society in the provision of qualified services for higher education.

All this will ensure both the harmonious development of the socioeconomic sphere of the state, and the spiritual and cultural development of each person.

\section{Main material}

The content of education is also determined by the educational need of society and the personal need for education. The maximum level of need corresponds to the type of culture and is expressed in the form of ideas about the normative ideal of an educated person. The educational need is local in nature and is determined by the scale of the state and its culture. In this case, education is framed by regulatory documents that make up public policy. Each state forms its own education system, which regulates the educational needs of the state. For example, in Japan, the education system is focused on the brilliant fulfillment of tasks in a group according to a given pattern, in America - an orientation on individual success and personal achievements.

The following mechanisms and levers for implementing the state educational policy can be distinguished:

- legal (the whole set of normative acts regulating the activity of the education system): the national law on education (in Japan - the national concept of education; in Armenia - the national doctrine of education); state standards in the field of education (the normative basis for the activities of a particular institution, followed by all) the system of accreditation and licensing of educational institutions; statutes of educational institutions;

- indirect mechanisms of influence: economic mechanisms (budget financing of education) - a system of extra-budgetary investments (the state creates customs and other benefits for those enterprises that invest in education); 
- ideological mechanisms (state regulation and reproduction of the prevailing ideology, the main mechanism is the content of the state standard).

Personal educational need is associated with the creation of the image of the world. This is the system of values, patterns of behavior that allows a person to navigate in the world around him. Society is an educational environment from which a person receives information necessary for orientation in the world around him. In this sense, a person has needs that go beyond the state education system. Factors determining the personal need for education are: place of residence (geographical factor); family traditions (social factor); financial situation (economic factor). The scale of educational needs is determined by the number of students who want to get or stay in the education system. In sociology, it is measured by the size of the student population. The scale of educational needs is affected by: the demographic factor; geographical factor; internationalization of education. The educational need has the property of expanded reproduction, that is, the higher the level of education, the higher the need for further education, in particular, higher ${ }^{1}$.

The Law of Ukraine "On Higher Education" gives the following definitions to the concepts of "higher education" and "content of higher education". Higher education - education that is acquired by a person in a higher educational institution as a result of a consistent, systematic and purposeful assimilation of the content of education based on full general secondary education and ends with a certain qualification based on the results of state certification. The content of higher education is a scientifically based system of didactic and methodically designed educational material, which is created taking into account social requirements for personnel with higher education and is determined by the standards of higher education for educational qualification, scientific and educational levels in the specialties defined in the relevant lists of specialties $^{2}$.

The current stage of political and socio-economic development, is inextricably linked with world development trends, the accession of our

\footnotetext{
${ }^{1}$ Ivan M. Gryshchenko, Svetlana V. Bebko (2014). The model of evaluating the efficiency of educational services market based on the balanced scorecard / Warszawa 2014. Społeczeństwo i Edukacja. Międzynarodowych i Edukacji HUMANUM, no 13(1), pp. 91-104.

2 Закон України «Про вищу освіту» 2014 р. / Верховна Рада України. Відомості Верховної Ради (BBP), 2014. № 37-38. Ст. 2004.
} 
country to the pan-European processes, requires fundamentally new approaches to the training of highly qualified personnel for all branches of the national economy, culture and higher education.

As you know, the main areas of cultural, educational, scientific and technical integration of Ukraine into the European Union are the introduction of European norms and standards in education, science and technology, and the spreading of our own cultural and scientific achievements in the EU. These steps, aimed at increasing the European cultural identity in Ukraine and integration into the pan-European intellectual-educational and scientific-technical environment are reflected in a number of generalizing works ${ }^{3,4}$.

The process of approaching Ukraine to Europe is taking place in several areas, one of which is educational. In 1999 The Ministries of Education of 29 countries signed the Bologna Declaration. With this act, the participating countries decided to create a single European educational and scientific space. After Ukraine joined the Bologna process, it was quite natural that there was a need for restructuring and improving the management of the higher education system and directing Ukrainian education to achieve a modern world level, update its content, forms and teaching methods, organizational foundations of construction and activities, increase the intellectual potential of Ukraine, increase the contribution in the development of the economy, science, education, culture of the country and the welfare of the people ${ }^{5}$.

Management is the process of subject's influence on a particular system (biological, technological) in order to organize this system, maintain, modify its structure, support, change the mode of activity, its program $^{6}$. The higher education system requires management, although management has qualitative differences regarding education: a person is not an object of activity, unlike a technological or any other system, a

\footnotetext{
${ }^{3}$ Ніколаєнко С.М. Сучасні тенденції і проблеми теорії управління інноваційними процесами в освіті. «Гуманітарний збірник» державного вищого навчального закладу «Переяслав-Хмельницьк. державн. педагогічн. Університет ім. Г. Сковороди» : наук.-теор. зб. Тернопіль : Асторія. 2008. C. 81-89.

${ }^{4}$ Приходько І.П. Інноваційні процеси в реформуванні вищої освіти. Інвестиції: практика та досвід. 2009. № 24. С. 97-100.

${ }^{5}$ Мусієнко I.I. Інноваційний розвиток освітньої системи як основа гарантування національної безпеки України: засади, механізми управління, напрями забезпечення : Монографія. Харків : ТОВ «Оберіг», 2011.368 с.

${ }^{6}$ Словарь психолога-практика / Сост. С.Ю. Головин. Мн. : Харвест; М. : АСТ, 2001. С. 636.
} 
person selectively refers to external influences. That is why managing the higher education system is very complex and requires a lot of attention.

Educational sphere management provides:

- determination of goals and objectives of educational institutions of all forms of ownership;

- institutionalization and formation of educational institutions;

- formation and organization of the implementation of planned decisions in the educational field;

- maintaining vital activities of educational institutions;

- control over the functioning and direction of development of educational institutions.

Education management technology is a sequential, focused process that has a cyclical nature and is formed through functions: specific types of managerial activity that provide the formation of techniques, methods of managerial impact on the educational sphere.

Functions of education management were formed in the process of creating a branched structural and functional system of the educational sphere of modern society, reflect the essence and content of managerial activity at all levels of management of this industry.

The concept of "public administration" is considered as an important indicator of the level of functioning of public authority, which directly administers public administration through a legislatively defined system of public authorities. The effectiveness of the management of public authorities is one of the necessary conditions for the successful functioning of the entire public administration system, an important component of which is the management of the higher education system.

Problems of the theory and practice of public administration and its relationship with public policy are analyzed in many works of scientists.

In the work of $\mathrm{V}$. Konnov ${ }^{7}$ various models of managing a higher educational institution, in particular a university, are analyzed, a review of the history of the development of the university as a public institution from the moment of the first European higher education institutions to the present day is presented. For example, the Bologna model suggested that the main goal is the training of specialists, the Paris model - that the main value is the pursuit of science, and the training of specialists is a secondary

\footnotetext{
${ }^{7}$ Коннов В., Репина М. Эволюция моделей университетского управления: от «Studiumgeneral» до «предпринимательского университета». Москва, Россия : МГИМО (У) МИД России, 2015. (Серия «Международные процессы). Т. 13. № 1. С. 35-47.
} 
task. In the future, the choice of one of these goals as a priority played a decisive role in determining the formats of university management. In the Napoleonic model of higher schools, the choice was clearly made in favor of learning, and in the Humboldt model in favor of research.

In the second half of the twentieth century, the leadership role shifted to the American model, which involved managing the university by analogy with a commercial enterprise based on an efficiency criterion.

The most detailed analysis of the social functions of the university, the implementation of which ensures its sustainable public support, was carried out by T. Parsons and J. Platt ${ }^{8}$. The authors identify five main tasks: mass higher education at the undergraduate level; scientific research; personnel self-reproduction of the scientific community; training specialists in areas requiring high, specialized qualifications; "Cultural Definition of a Situation" - in essence, intellectual activity.

Thus, if it is possible to maintain unity in the implementation of scientific, educational and social functions, it provides, if not always measurable, but a significant advantage, due to which the university throughout its history has been associated with high-level intellectual standards.

Today, the management of the higher education system of Ukraine is in the process of constant changes. On the one hand, this requires improving the mechanism of public administration of education, in particular, developing fundamentally new approaches to forms and methods of management, determining scientifically sound regulatory and legal aspects of state regulation. On the other hand, the organizational and economic structure of institutions of higher education in the context of globalization and innovative development no longer meets the modern objective needs of society, in particular, it becomes necessary to create a single effective information system for higher education institutions.

Public administration of the higher education system in the countries of the world is developing and transforming under new conditions - the centralized tight control is being replaced by the flexible management of autonomous higher education institutions, and the impact on their activities is carried out using various organizational and economic approaches and tools.

\footnotetext{
${ }^{8}$ Parsons T., Platt G. The American university. Cambridge : Harvard University Press, 1973. 474 p.
} 
If we consider the management models in the system of higher education in developed countries in terms of their diversity and community, it is necessary to determine the integration factors in the development of this social phenomenon. These include historical, political and social conditions; cultural and national traditions, views; current international trends. According to a unanimous assessment of Western scholars, it is precisely stated, not scientifically based arguments, and recommendations on a rational planning and examination system that play a leading role in the creation and development of models in the management of higher education in Western Europe.

The organization of management and control of the higher education system of different countries is extremely different from autonomy (Germany) - to control by state national services (England) and direct instructions of the government and the Minister of National Education (France $^{9,10,11}$.

The United States has far back understood that the level of development of education and science determines the authority of the country, its political importance in the international arena. There twice as much is allocated for education than for military needs. Specialists with higher education (and they make up 25\% of employees) produce $56 \%$ of the gross product. According to the calculations of American economists, investment in primary school gives $40 \%$ of the profit, on average $-10 \%$, and in higher education $-340 \%{ }^{12}$.

An analysis of the mechanisms of managing the higher education system of developed countries makes it possible to see the diversity of centralized and decentralized types of governance and proves that each of them has a different effect on the development of the country's higher education system. The most important sign of a high level of development and democratization of public administration is active participation in the management of local government education, which has a complex structure of executive bodies. In improving the mechanisms of state regulation of the

\footnotetext{
${ }^{9}$ Ахтамзян Н.А. Система государственно-общественного управления образованием в Германии. URL: http://www.portalus.ru/modules/shkola/rus_readme.php?subaction=showfull\&id=1193316900\&archive= $1195596940 \&$ start_from $=\& u c a t=\&$.

${ }^{10}$ Василенко И.А. Административно-государственное управление в странах Запада: США, Великобритания, Франция, Германия. URL: http://dmeti.dp.ua/file/vasilenko_i._a._administrativnogosudarstvennoe_upravlenie_v_stranah_zapada_lbr_2001_rbr_pdf.

${ }_{11}^{11}$ Камозіна Н. Державно-громадська модель освіти у Франції. URL: http://osvita.ua/school/manage/1776//

12 Джонстоун Д.Б. Система высшего образования в США: структура, руководство, финансирование. URL: http://www.umj.ru/index.php/pub/inside/390.
} 
higher education system in Ukraine, best practices should be used to improve the management processes of higher educational institutions in modern market conditions. This is the most important task, since the national management system of higher education institutions requires modernization and improvement. The process of integration into the European Union in the field of higher education in Ukraine should be more conceptual and progressive.

The analysis of the development process of the public education management system is dedicated to the works of B. Danylyshyn, I. Zhyvotovska, S. Zaretska, I. Ishyna, K. Korsak, V. Luhovyi, A. Yaryshko and others.

Transformational changes in society require improvement of the higher education system of Ukraine, therefore it requires new approaches, in particular, to the current practice of financing it.

In the work of $\mathrm{L}$. Yaremenko ${ }^{13}$ is proposed a dynamic model of financial and economic flows of universities based on a multi-purpose approach in the formation of a development strategy, a combination of public and private financing and adaptation to changing market conditions. The main direction of increasing the efficiency of financial and economic activities is the formation of a vector of strategic goals of universities and their timely adjustment. However, the proposed model does not allow solving the problems of macroeconomic planning of training specialists with higher education.

O. Tymoshenko ${ }^{14}$ analyzed approaches to assessing the level of financial independence of a higher educational institution, allowing to identify the effectiveness of various forms of financing its activities by calculating the degree of satisfaction of planned needs for funding (in general and separately from budget and extra-budgetary sources) and assess the type of financial stability of a higher educational institution institutions, the classification of which, in addition to the traditional approach, provides for the differentiation of the crisis type of financial condition in the context of extrabudgetary, budgetary and general underfunding.

\footnotetext{
${ }^{13}$ Яременко Л.М. Організаційно-економічні механізми державного управління вищою освітою в Україні. Потенціал економічного розвитку в контексті Європейської інтеграції : зб. наук. праць. URL: http://perspektyva.dp.ua/files/articles/ 06.07.2013.pdf.

${ }_{14}$ Тимошенко О.В. Фінансовий механізм функціонування та розвитку системи вищої освіти в Україні [Текст] : дис. канд. екон. наук : 08.00.08. Державний вищий навчальний заклад «Українська академія банківської справи Національного банку України». Суми, 2010. 228 с.
} 
The object of the study to assess financial stability in this case is the higher educational institution, which is part of the scientific and innovative university association. It is a complex system, the main properties of which are: the ability to carry out educational, research and innovative activities; receive budget funds and extrabudgetary revenues to compensate for expenses incurred.

The methodological approach to the financial stability of the university, proposed by the author, involves taking into account the level of satisfaction of the university's planned funding needs from various sources, but this does not solve the main task of macroeconomic planning of specialist training, the regional factor is not taken into account, and the problems of financing the higher education system as a whole are not solved that requires further scientific development.

To assess the quality of higher education, its characteristics are established, and E. Korotkov proposes to consider the whole range of such characteristics in five groups, for each of which their list is established by at least four most important criteria, and suggests using them for assessment, research, analysis and recommendations by the quality of higher education. Each of these criteria can be evaluated by a certain set of universal interconnected and complementary approaches: computer testing, business game, case analysis, role play, analysis of accumulated information, sociometric studies, self-assessment of training, designing strategies, plans, concepts, software and analytical assessment writing work ${ }^{15}$.

The examination of the quality of education, the European approach and the optimization of criteria for assessing the quality of higher education in Ukraine are covered in many scientific works.

Thus, the basis of quality management in institutions of higher education is to monitor the compliance of students' actual knowledge with the standards that were made in the teaching of each discipline, and to achieve this goal a model of an adaptive system model $^{16}$, is proposed that allows you to take into account the individual characteristics of the student in distance learning and knowledge control.

\footnotetext{
${ }^{15}$ Коротков Э.М. Управление качеством образования: учебное пособие для вузов [2-е изд.]. Москва : Академический Проект, 2007. С. 252.

${ }^{16}$ Федорук П.І. Модель адаптивної системи дистанційного навчання і контролю знань. Комп'ютерне моделювання та інформаційні технологї в науці, економіці та освіті : Зб. наук. праць. Кривий Ріг : КЕI КНЕУ, 2005. С. 223-224.
} 
Many researchers working on the creation of automated systems for assessing students' knowledge have proved that the advantage of such systems is to increase the objectivity of assessment, and the disadvantage is the subjective properties of the standard, with which the student's actual knowledge in each discipline is compared.

In the work of M. Karpenko ${ }^{17}$ is examined the process of monitoring the quality of higher education. The proposed model summarizes the model of cyclical verification of quality assurance agencies adopted in the European Higher Education Area. The considered mathematical apparatus can be replenished with new types of controlled objects, indicators of their quality, assessment models.

In some scientific works, state control and monitoring of the quality of educational services implemented through licensing, certification and accreditation of universities are analyzed. By definition of N. Zhyhotska ${ }^{18}$, all indicators are divided into two groups. The first group consists of qualitative and quantitative indicators, the presence of which confirms the readiness of the institution to provide educational services. The second group consists of quantitative indicators (in absolute terms or in percent), the value of which should be no less than the standards that are determined by experts and are firmly established. In fact, experts are only able to indicate the intervals within which the quantitative values of the relevant indicators can be.

However, in all the cited works, in examining the process of monitoring the quality of the higher education system, the important issue of the educational capacities of higher educational institutions was not considered.

The serious attention of researchers in the management of the quality of education confirms the importance of this problem and at the same time poses new tasks, without the solution of which further improvement of quality is constrained. One of the most important of these tasks is the development of a methodological approach and criteria for assessing the quality of training of specialists in comparison not with the standard ones developed by teachers of each discipline (that is,

\footnotetext{
${ }^{17}$ Карпенко М. Система забезпечення якості вищої освіти у Болонському процесі та механізми їі імплементації в Україні. Аналітичні записки. 2008. № 6. URL: http://www.niss.gov.ua/Monitor/ juni08/16.htm.

${ }_{18}$ Жигоцька Н.В. Комбінований метод визначення вагових коефіцієнтів у рейтинговій оцінці вищого навчального закладу. Зб. наук. праць за матеріалами Міжнар. наук.-практ. конф. «Ризикологія 8 економіці та підприємництві». Київ : КНЕУ, Академія ДПС України, 2001. С. 150-151.
} 
inside universities), but in comparison with the requirements that the external sphere of activity in which a graduate of a higher educational institution will apply his knowledge and skills. In addition, taking into account quality approaches is realistic when considering educational planning.

Research and development of new theoretical, methodological and practical approaches to planning the activities of higher education institutions has a significant gap with similar processes aimed at industrial or construction enterprises. However, in recent years, the interest of researchers in the development of a methodology and scientifically based practical recommendations for planning individual processes of the activity of air defense has significantly increased.

The completed developments are aimed at solving certain issues of university management, its financing and the like. As a rule, this applies to state educational institutions in which limited funding raises the problem of rational (optimal) use of budget funds.

Some of the most important aspects of the functioning of the stateowned public domain of ownership in a transformational economy are considered. In particular, the issues of managing the social sphere were examined.

In this work, the features of the social and domestic sphere of activity of a state institution of higher education, which operates in the conditions of the transformational economy of Ukraine, are researched. The management concept is presented, which helps to reduce the level of utility costs and increase the flow of funds from functional activities. Within its framework, a model of such a management system of a state university allows you to regulate the cost of services to the housing and communal sector, plan settlements in dormitories of the campus, provide additional scholarships and subsidies to pay for housing and communal services, and quickly manage the financial discipline of residents of hostels. The structure of the complex of information support of decisions in the management of social and household activities of a state institution of higher education is proposed, which is based on the concept of a distributed database. Also considered are internal and interorganizational virtual formations in the social-everyday sphere of activity of a state institution of higher education. 
Another work ${ }^{19}$ is devoted to the construction of a system of managing the economic activity of a state institution of higher education, and it is proposed to consider the cost of student learning as the main economic indicator for evaluating the activities of a university. The WHO business management process consists in planning supplies and stocks of resources, in choosing suppliers of material resources, in monitoring the work of materially responsible persons. WHO business management models have been developed: cost management for training; inventory planning and accounting; assessments of suppliers of material resources, as well as determining the performance of materially responsible persons. A complex of information support for decisions in the system of economic management of the state WHO is proposed.

Thus, the concept of organizing the management of an economic object in the structure of a higher education institution using the principles of a systematic approach, reengineering and the theory of multidimensional systems is developed, which allows to increase the stability of an economic object in market conditions. The object of management is the campus. A set of management models has been created for it, in particular, financial resources, rating personnel, evaluating the economic efficiency of the information-analytical management system. But the main attention in the tasks of planning the activities of the university, as the analysis of the completed developments shows, is paid to the planning of the social sphere, economic activity, stocks of material resources and the assessment of their suppliers to educational institutions, the campus as an object of management, although in modern conditions of a competitive economy, is important the issue of forecasting and macroeconomic planning of demand for university services and decision-making to achieve the desired number of specialists with higher education for the national economy.

Of particular relevance are the issues of flexible response of the training system to requirements that are constantly changing, and the needs of the labor market in Ukraine, as well as the problems of providing regions with specialists, which are one of the main factors for the effective development of economic sectors in the country.

A significant contribution to solving issues related to the formation of the labor market for specialists with higher education and the development

\footnotetext{
${ }^{19}$ Шамарін Ю.В. Моделювання системи управління господарчою діяльністю державного ВНЗ, що функціонує в трансформаційній економіці України : автореф. дис. на здобуття наук. ступеня канд. екон. наук : 08.03.02. Донец. нац. ун-т. Донецьк, 2001. 18 с.
} 
of higher education in the country was made by such scientists as V.I. Kutsenko, I.K. Bondar, D.P. Bohynia, O.A. Hrishnova, V.M. Daniuk, H.A. Dmytrenko and others.

Research on this problem is constantly in the attention of other scientists and economists who have studied the problems of methodological approaches to determining the need for highly qualified specialists and the volume of their training. However, the important theoretical and practical significance of these problems, modern economic realities and requirements make it necessary to continue research on these issues.

Macroeconomic planning and forecasting arose during the twentieth century in the process of economic development as a form of its regulation. It is known that planning is a product of the socialist system, which as authoritarian and centralized was developed in the former USSR, and then in other socialist countries. Over time, it has spread to developed countries with market economies, including the USA, Japan, France, Germany, etc.

This was especially noticeable in the post-war period. This was influenced by the following factors: the need to restore the economy destroyed by the Second World War, the recognition of the new role of the state and the need for its intervention in the regulation of economic growth and, in particular, competition in the former socialist camp.

Thus, despite the fact that planning is a product of the socialist system, it has rapidly spread throughout the world as a form of state regulation of the economy.

For example, in the work of V. Makarov, forecasting the need for specialists in the consumer cooperation of the USSR was considered. Based on the proposed methodology, a forecast was made in two versions - the general and additional needs for specialists in the cooperative sector of the economy, which reduced the possibility of imbalances in the training of specialists. However, it is possible to use this forecasting technique with clarifying the main ways and prospects of the economic system evolution, possible structural changes in it, the priority directions of the socio-economic progress and the transition of our country to a market economy. 
In the work of T. Ogarenko ${ }^{20}$ the author took as a basis the hypothesis that the demand for WHO educational services in the next year depends on the demand in the current year.

Considering the influence of the demographic situation in the region and the assumptions made about the types of control influence of the university, the author obtained a predictive non-linear dynamic model of the demand for WHO educational services (without taking into account the level of education quality).

Unfortunately, the higher education system is not stable enough, and decisions can change over several years. For example, in the 2006/07 academic year, 507.7 thousand students were admitted, and in 2017/18 264.4 thousand.

Today, the demand for educational services is formed under the influence of many factors, the main of which are the structure of specialties in educational institutions formed over the years, the demand from the population, the state order and the demand of employers. The reports of the Accounts Chamber of Ukraine on the results of inspections of the use of funds of the State Budget of Ukraine for personnel training indicate a national problem - a significant number of specialists receiving higher education and vocational education are not employed in their specialty, and the demand for specialists in the labor market has not yet become the determining criterion for assessing the effectiveness of the institution. This situation is due to the lack of a worked out mechanism of interaction between the Ministry of Education and Science, the Ministry of Labor and Social Policy, educational institutions, employment centers and enterprises.

In general, educational standards are outdated, educational institutions due to low material and technical support, a lack of information on the needs of the economy for personnel are more often guided by the commercial interests of satisfying the population's demand for educational services. This leads to the fact that the population receives education, using their own considerations regarding the prestige of individual specialties and the need for relevant specialists. Such stereotypes are not always objective and is the reason for the formation of human resources, which does not correspond in quantity and quality to the needs of the modern labor market. Employers who are buyers of labor practically do not

\footnotetext{
${ }^{20}$ Огаренко Т.Ю. Нелінійна динамічна модель попиту на послуги вищих навчальних закладів. Економічні науки. Вісник Запорізького національного університету. 2010. № 2 (6).
} 
participate in the training process. The fragmentation of the goals and interests of suppliers and buyers of labor leads to vocational qualification structural deformation and a shortage of qualified personnel. Due to the lack of their constructive interaction, the market mechanism for staffing the Ukrainian economy has low efficiency. Obviously, employers should be more actively involved in the training process in the educational system, in particular higher education, for which a wide range of means and forms has been accumulated.

In world society, $30-50 \%$ of the university's budget is formed at the expense of employers, which gives them the opportunity to participate in the educational process, to stimulate the improvement of the quality of education and its use for the development of skills directly beneficial to business.

Thus, we can conclude that in Ukraine today there are effective directions and prospects for establishing close cooperation between science, education and business, requiring the formation of a regulatory framework in the field of encouraging employers to participate in the training and employment of personnel, improving organizational forms of cooperation and implementing new forms of interaction "university science- business" in the framework of international projects. The integrated implementation of these activities will help bring educational services closer to the needs of employers.

When predicting the demand for educational services of universities, S. Semeniuk ${ }^{21}$ took into account the fact that demand is influenced by factors such as the price of educational services, the number of graduates in the region, and the incomes of the region's population. An approach to assessing the competitiveness of universities has also been developed, based on indicators significant for the consumer, established as a result of the survey in determining the degree of influence on individual demand, taking into account their actual weight. But the author does not take into account the needs of the labor market for certain specialists by region and in the country as a whole.

The concept of researching the dynamics of demand for university services proposed by T. Ogarenko ${ }^{22}$ includes five stages:

\footnotetext{
${ }^{21}$ Семенюк С.Б. Кон'юнктура ринку освітніх послуг вищих навчальних закладів. Рукопис. URL: https://www.google.com.ua/search?hl=uk\&source=hp\&q.

22 Огаренко Т.Ю. Концепція моделювання динаміки попиту на послуги вищих навчальних закладів. Ефективна економіка. 2010. № 10. URL: http://www.economy.nayka.com.ua/?op=1\&z=350.
} 
I - Determination of factors of motivation for applicants to enter universities.

II - Modeling the dynamics of demand for university services.

III - Formation of control action.

IV - Implementation of the control action.

$\mathrm{V}$ - Evaluation of the effectiveness of the application of control action.

At the first stage, it seems appropriate to identify significant factors for the motivation of applicants to enter universities.

At the second stage, the dynamics of demand for services of higher educational institutions is simulated. The complexity of direct experimental research of the processes of formation of demand for educational services necessitates the construction of adequate models of demand dynamics. At this stage, the question arises, what methods and models should be used to model the dynamics of demand for university services. The course of the processes of formation of demand for educational services of a university in time determines the need to use dynamic models for their modeling.

At the third stage, the formation of the university's control effect takes place, which consists in the adoption of appropriate decisions by the administration of the educational institution to achieve the desired level of demand.

At the fourth stage, the implementation of the formed control actions takes place. At the last, fifth, stage, the effectiveness of the applied managerial impact is assessed. By efficiency, the author understands the excess of additional income that will be received from attracting an additional number of students to training over the costs of implementing management methods. The university should choose management methods that will enable it to achieve the goal of recruiting students with the least involvement of resources.

But the methodological approaches of macroeconomic planning in the management of the higher education system, which could provide an increase in its effectiveness, were not considered in the work.

So, the analysis showed that the urgent problem of the development of the national economy is the imbalance between the real needs of the labor market for specialists of a certain competence and the proposal that is formed by graduates of higher educational institutions. The consequence of 
this is certain imbalances in the labor market, in particular, its oversaturation by specialists with higher education in certain specialties. Such problems are inherent not only in Ukraine and the CIS countries, but also in the labor markets of Europe, the USA and other countries, and therefore are considered global.

The main reason for this situation in our country is the lack of an effective system of macroeconomic planning of labor market needs for certain specialists with higher education.

The audit materials of the Accounts Chamber of Ukraine showed that the higher education system and the state order mechanism do not correspond to the realities of the modern labor market, do not provide a balance of needs and proposals, and therefore, the efficient use of budget funds is not ensured.

The audits proved that the allocation of budgetary funds for the maintenance of universities, in accordance with the budget and the university's capacity to provide educational services, did not optimize departmental systems for the training of specialists and staff development taking into account the forecasted needs of industries. The main managers of the budget funds were not provided with a study of the real needs of the industries that are subordinate to them, and the volume of the state order for training and advanced training was formed on the basis of proposals from subordinate educational institutions that focused on the order of previous years, their own possibilities of providing educational services and the demand of applicants.

In addition, the legislative and organizational uncertainty of the mechanism for the formation of the need for training for state orders contributes to the collective irresponsibility of both central and local authorities, which leads to an increase in the imbalance between the real need of regional labor markets and the volume of training of specialists by profession and, despite the measures taken by the ministries in the field of training specialists, the needs of the labor market and the market for educational services there is no guaranteed provision of the first workplace to graduates who studied by state order, including in targeted areas.

Thus, in the formation of the state order, the real need for specialists is either not determined at all or ignored, although this is crucial to ensure the efficient use of budget funds for the training of specialists. 
The state order of the university, in the absence of a predicted need for personnel and macroeconomic planning, is formed on the basis of their own capabilities and demand of applicants. Contracts are not concluded between state customers and executors of state contracts, therefore, the parties are not responsible for the inconsistency of needs and proposals for training.

In the work of $\mathrm{O}$. Hryhorieva ${ }^{23}$ it is noted that the forecast for the development of the higher education system takes a leading place in the system of scientific, technical, economic and social forecasts. Forecasting training of specialists is closely connected with other branches of scientific forecasting. The factors on which the volumes of training specialists for the future depend, have the following parameters: forecast for the development of individual sectors of the national economy and economic regions; changes in the demographic situation; material, labor, financial capabilities of the state; social consequences of mass training.

As one of the ways to solve the problem of the number of specialists with higher education necessary for the national economy, the use of the method of saturation by specialists from the definition of the norm of saturation by WHO specialists is proposed.

The proposed in the work approach to determining the prospective need for specialists with higher education can be used to regulate the demand and supply of highly skilled labor in the labor market, but the statistics are unstable, the reliability of information is low, and failure to receive information on any of the above indicators leads to the termination of the process macroeconomic planning of higher education.

The main attention in the tasks of planning the activities of higher education institutions, as the analysis of the completed studies shows, is given to the planning of the social sphere, economic activity, inventories of material resources and the assessment of their suppliers to educational institutions, the campus as an object of management, etc.

The solution to these problems is relevant and of practical importance, but it should be borne in mind that, in accordance with the logical and informational connections of tasks in the management system, they have a value depending on the tasks of planning the main activity of higher educational institutions. In this regard, the task of studying the basic processes of higher education management and developing methods for

\footnotetext{
${ }^{23}$ Григор'єва О.В., Васюта В.Б., Васюта В.В. Методичні підходи до визначення потреби в спеціалістах із вищою освітою. Вісник Полтавської державної аграрної академї. 2012. № 3. URL: http://www.pdaa.edu.ua/sites/default/files/visnyk/2012/03/148.pdf.
} 
planning the activities of educational institutions is becoming particularly relevant.

Successful implementation of state policy in the field of higher education is impossible now without using modern approaches to macroeconomic planning and forecasting demand for specialists of a certain level and direction of education.

\section{CONCLUSIONS}

For Ukraine, the problems of involving all possible factors of economic growth, among which a prominent place belongs to higher education, are of particular relevance, but in the conditions of economic transformation, higher education is faced with the problem of survival and self-sufficiency, which in turn leads to structural imbalances and the mismatch of the higher education system with the needs of the economy.

In order to improve methodological approaches to macroeconomic planning and forecasting in the management of the higher education system, the relevant existing conceptual and scientific-practical approaches to management in the higher education system have been evaluated, their shortcomings and the restrictive nature of practical use have been revealed. Based on its results, it was concluded that the main tasks of macroeconomic planning and forecasting the training of specialists are now practically not being solved, the regional factor is not taken into account, the monitoring capacities of higher education institutions are not taken into account in monitoring the quality of the higher education system, and the problems of financing the higher education system are not resolved, that is, existing methods and approaches do not reflect the full range of issues, the solution of which will provide the national economy with the necessary specialists.

Thus, the analysis of foreign and domestic scientific sources, the areas of research of the essence and the specific problems of the features of methodological approaches and models in the management of the higher education system make it possible to draw conclusions about the need to improve the planning of training of specialists with higher education, taking into account the needs of the economy in specialists, the educational capacities of institutions of higher education education, budget constraints and the direction to maximize the proportionality of the security $\mathrm{s}$ economic activities by the necessary qualified specialists. 


\section{REFERENCES}

1. Ivan M. Gryshchenko, Svetlana V. Bebko (2014). The model of evaluating the efficiency of educational services market based on the balanced scorecard / Warszawa 2014. Społeczeństwo i Edukacja. Międzynarodowych i Edukacji HUMANUM, no 13(1), pp. 91-104.

2. Закон України «Про вищу освіту» 2014 р. / Верховна Рада України. Відомості Верховної Ради (ВВР), 2014. № 37-38. Ст. 2004.

3. Ніколаєнко С.М. Сучасні тенденції i проблеми теорії управління інноваційними процесами в освіті. «Гуманітарний збірник» державного вищого навчального закладу «ПереяславХмельницьк. державн. педагогічн. Університет ім. Г. Сковороди» : наук.-теор. зб. Тернопіль : Асторія. 2008. № 13. С. 81-89.

4. Приходько І.П. Інноваційні процеси в реформуванні вищої освіти. Інвестиції: практика та досвід. 2009. № 24. С. 97-100.

5. Мусієнко I.I. Інноваційний розвиток освітньої системи як основа гарантування національної безпеки України: засади, механізми управління, напрями забезпечення : Монографія. Харків : ТОВ «Оберіг», 2011. 368 с.

6. Словарь психолога-практика / Сост. С.Ю. Головин. Мн. : Харвест; М. : АСТ, 2001.

7. Коннов В., Репина М. Эволюция моделей университетского управления: от "Studium general" до «предпринимательского университета». Москва, Россия : МГИМО (У) МИД России, 2015. (Серия «Международные процессы). Т. 13. № 1. С. 35-47.

8. Parsons T., Platt G. The American university. Cambridge : Harvard University Press, 1973. 474 p.

9. Ахтамзян Н.А. Система государственно-общественного управления образованием в Германии. URL: http://www.portalus.ru/ modules/shkola/rus_readme.php?subaction=showfull\&id=1193316900\&ar chive $=1195596940 \&$ start_from $=\& u c a t=\&$

10. Василенко И.А. Административно-государственное управление в странах Запада: США, Великобритания, Франция, Германия. URL: http://dmeti.dp.ua/file/vasilenko_i._a._administrativno-gosudarstvennoe_ upravlenie_v_stranah_zapada_lbr_2001_rbr_.pdf.

11. Камозіна Н. Державно-громадська модель освіти у Франції. URL: http://osvita.ua/school/manage/1776 
12. Джонстоун Д.Б. Система высшего образования в США: структура, руководство, финансирование. URL: http://www.umj.ru/ index.php/pub/inside/390.

13. Яременко Л.М. Організаційно-економічні механізми державного управління вищою освітою в Україні. Потенціал економічного розвитку в контексті Європейської інтеграиії : зб. наук. праць. URL: http://perspektyva.dp.ua/files/articles/06.07.2013.pdf.

14. Тимошенко О.В. Фінансовий механізм функціонування та розвитку системи вищої освіти в Україні [Текст] : дис. канд. екон. наук : 08.00.08. Державний вищий навчальний заклад «Українська академія банківської справи Національного банку України». Суми, 2010. $228 \mathrm{c}$.

15. Коротков Э.М. Управление качеством образования : учебное пособие для вузов [2-е изд.]. Москва : Академический Проект, 2007. $320 \mathrm{c}$.

16. Федорук П.І. Модель адаптивної системи дистанційного навчання i контролю знань. Комп'ютерне моделювання та інформаційні технологї̈ в науиі, економіиі та освіті : Зб. наук. праць. Кривий Ріг : КЕI КНЕУ, 2005. С. 223-224.

17. Карпенко М. Система забезпечення якості вищої освіти у Болонському процесі та механізми тї імплементації в Україні. Аналітичні записки. 2008. № 6. URL: http://www.niss.gov.ua/ Monitor/juni08/16.htm.

18. Жигоцька Н.В. Комбінований метод визначення вагових коефіцієнтів у рейтинговій оцінці вищого навчального закладу. Зб. наук. праць за матеріалами Міжнар. наук.-практ. конф. «Ризикологія в економіuі та підприємництві». Київ : КНЕУ, Академія ДПС України, 2001. C. $150-151$.

19. Шамарін Ю.В. Моделювання системи управління господарчою діяльністю державного ВНЗ, що функціонує в трансформаційній економіці України : автореф. дис. на здобуття наук. ступеня канд. екон. наук : 08.03.02. Донец. нац. ун-т. Донецьк, 2001. 18 с.

20. Огаренко Т.Ю. Нелінійна динамічна модель попиту на послуги вищих навчальних закладів. Економічні науки. Вісник Запорізького національного університету. 2010. № 2 (6). 
21. Семенюк С. Б. Кон'юнктура ринку освітніх послуг вищих навчальних закладів. Рукопис. URL: https://www.google.com.ua/ search?hl=uk\&source $=$ hp\&q

22. Огаренко Т. Ю. Концепція моделювання динаміки попиту на послуги вищих навчальних закладів. Ефективна економіка. 2010. № 10. URL: http://www.economy.nayka.com.ua/?op=1\&z=350

23. Григор'єва О.В., Васюта В.Б., Васюта В.В. Методичні підходи до визначення потреби в спеціалістах із вищою освітою. Вісник Полтавської державної аграрної академії. 2012. № 3. URL: http://www.pdaa.edu.ua/sites/default/files/visnyk/2012/03/148.pdf.

\section{Information about the authors:}

Klymeniuk M. M.

Doctor of Economics, Professor, Head of Department of Management and

International Economic Relations, V. I. Vernadsky Taurida National University 33, John McCain str., Kyiv, 02000, Ukraine 